\title{
PENGEMBANGAN PERANGKAT PEMBELAJARAN KIMIA MODEL INKUIRI UNTUK MENINGKATKAN PENGUASAAN KONSEP DAN MELATIH KETERAMPILAN BERPIKIR KRITIS SISWA SMA
}

\author{
Zaiful Anam Hadi Saputra'), Leny Yuanita ${ }^{2)}$, Muslimin Ibrahim ${ }^{3)}$ \\ ${ }^{1)}$ Mahasiswa Program Studi Pendidikan Sains, Program Pascasarjana Universitas Negeri Surabaya \\ ${ }^{2), 3)}$ Dosen Pascasarjana Prodi Pendidikan Sains Universitas Negeri Surabaya \\ E-mail: anam03924@gmail.com
}

\begin{abstract}
Abstrak: Telah dilakukan penelitian pengembangan perangkat pembelajaran model inkuiri dengan pendekatan scientific yang menggunakan 4-D model dan bertujuan untuk meningkatkan penguasaan konsep dan keterampilan berpikir kritis pada materi koloid di SMA. Subyek penelitian perangkat pembelajaran yang diujicobakan pada siswa kelas XI IPA SMAN 6 Surabaya dengan rancangan one group pretest-posttest, sedangkan data hasil penelitian yang diperoleh sebagai berikut: validasi RPP, buku siswa dan LKS berkategori layak, tes penguasaan konsep dan tes berpikir kritis berkategori valid. Keterlaksanaan RPP berkategori baik. Aktivitas siswa dalam pembelajaran mengalami peningkatan yang tinggi, Siswa memberikan respon positif terhadap proses pembelajaran, serta ketuntasan penguasaan konsep dan keterampilan berpikir kritis telah tercapai. Simpulan penelitian ini, bahwa perangkat pembelajaran kimia model inkuiri dengan pendekatan scientific layak dan dapat meningkatkan penguasaan konsep dan melatih berpikir kritis siswa SMA.
\end{abstract}

Kata kunci: Model Inkuiri, Penguasaan Konsep, Berpikir Kritis

Abstract: Research development of chemistry teaching materials inquiry model with scientific approach has been done by using 4-D model which aims to increase the student concept mastery and critical thinking skills on coloid topic at senior high school. The research subject of teaching materials which tested on student of science class $11^{\text {th }}$ grade in senior high school 6 Surabaya with one-group pretest-posttest design, the results from the research show that the lesson implementation plan, the student's book and student's worksheet were feasible, then the validation instrument were valid. Implementation of lesson plan was good, the activity of student in learning process has increased highly, students gave the positive response to learning process, as well as concept mastery and practicing critical thinking has been achieved. The conclusion of this research, show that the chemistry teaching materials of inquiry model with scientific approach is feasible and able to increase concept mastering and practicing critical thinking of students in Senior High School.

Keywords: Inquiry Model, Concept Mastery, Critical Thinking

\section{PENDAhuluan}

Berdasarkan hasil penelitian Tim Survey IMSTEPJICA (1999) di kota Bandung menemukan bahwa sejumlah kegiatan pembelajaran di sekolah yang menuntut kemampuan berpikir kritis dianggap masih rendah karena siswa merasa sulit mempelajari mengenai pembuktian pemecahan masalah yang memerlukan penalaran matematis dan menemukan hubungan antara data-data atau fakta yang diberikan. Dengan demikian siswa mengalami kesulitan jika dihadapkan kepada persoalan yang memerlukan kemampuan berpikir kritis.

Indikasi masih rendahnya hasil pembelajaran sains di sekolah juga dapat dilihat dari laporan PISA dan TIMSS. Menurut PISA (Program for Internasional Student Assesment) tahun 2012, Indonesia berada di urutan 64 dari 65 negara yang di survey. Kemampuan siswa di Indonesia dalam hal pelajaran sains terutama untuk konteks aplikasi sains terbukti bahwa banyak siswa di Indonesia tidak dapat mengkaitkan pengetahuan sains yang dipelajarinya dengan fenomena-fenomena yang ada dalam kehidupan seharihari. Data tersebut menunjukkan bahwa pembelajaran sains di Indonesia belum mampu meningkatkan keterampilan berpikir siswa.

Sementara itu dari hasil TIMSS (Trends International in Mathematics and Science Study) tahun 2011, menunjukkan bahwa hasil belajar siswa Indonesia lebih dominan pada dimensi pengetahuan, sedangkan dimensi penalaran dan penerapan jauh lebih rendah. Rendahnya penerapan dan penalaran (keterampilan berpikir) siswa disebabkan proses pembelajaran yang lebih ditekankan pada aspek pengetahuan (produk) bukan pada proses, sehingga 
anak kurang diasah kemampuan berpikirnya. TIMSS merupakan proyek penelitian kolaboratif yang disponsori oleh the International Association for the Evaluation of Educational Achievement (IEA).

Hasil observasi di sekolah sasaran penelitian menunjukkan bahwa proses pembelajaran masih bersifat hafalan dan kurang mengembangkan proses berpikir, terutama pada penanaman konsep masih diterapkan di SMAN 6 Surabaya. Berdasarkan pada studi pendahuluan melalui angket respon siswa terhadap pembelajaran kimia yang diberikan kepada 38 siswa kelas XII IPA1 semester 1 SMAN 6 Surabaya tahun akademik 2014/2015 pada bulan september 2014, 31 siswa menyatakan bahwa siswa tidak menyenangi pelajaran kimia, akibatnya motivasi siswa dalam belajar kimia rendah, hal ini didukung dengan keaktifan bertanya siswa ketika pembelajaran berlangsung, 34 siswa menyatakan bahwa siswa jarang bertanya ketika proses pembelajaran berlangsung meskipun mereka tidak memahami tentang materi yang diajarkan. Selain itu, 35 siswa berpendapat bahwa dalam pembelajaran kimia identik dengan rumus-rumus kimia, perhitungan dan hafalan, sehingga pelajaran kimia menjadi pelajaran yang tidak menarik, tidak menyenangkan, bahkan dibenci. Pandangan negatif ini diperparah lagi dengan metode belajarnya yang kurang bervariasi, 31 siswa menyatakan bahwa pada umumnya pembelajaran yang dilakukan oleh guru ketika pembelajaran kimia berlangsung adalah ceramah. Akibatnya siswa menjadi lekas bosan dan tidak tertarik pada pelajaran kimia. Hal tersebut berdampak pada cara belajar siswa, 35 siswa menyatakan bahwa siswa belajar dengan cara menghafal materi dan menghafal soal-soal yang telah diberikan, akibatnya siswa tidak memahami dan menguasai konsep dari materi yang diajarkan sehingga siswa merasakan kesulitan ketika belajar kimia (34 siswa menyatakan bahwa siswa merasa kesulitan ketika belajar kimia). Salah satu materi kimia yang dianggap sulit dan tidak disukai oleh siswa adalah materi koloid. Sebanyak 16 siswa $(42,1 \%)$ menyatakan tidak menyukai materi koloid dan sebagian lainnya menyatakan kurang memahami materi tersebut, akibatnya adalah banyak siswa yang harus mengikuti ujian perbaikan untuk mencapai ketuntasan belajar.

Pengkajian yang dilakukan terhadap perangkat pembelajaran di SMAN 6 Surabaya ditemukan bahwa perangkat pembelajaran tersebut pada umumnya berisi kegiatan yang berorientasi pada penguasaan konsep Kimia. Langkanya perangkat pembelajaran penunjang eksperimen untuk menguji hipotesis menjadi salah satu sebab mengapa keterampilan berpikir kritis dan penguasaan konsep siswa belum diajarkan secara maksimal. Oleh karena itu, untuk menilai hasil belajar siswa, di sekolah tersebut guru hanya menggunakan lembar penilaian produk saja. Hal ini sejalan dengan sejumlah penelitian yang telah dilakukan Pusat Sains dan Matematika Sekolah (PSMS) Unesa sejak tahun 1991, memberi bukti kuat bahwa perangkat pembelajaran berkualitas merupakan salah satu prasyarat terwujudnya pendidikan berkualitas (Nur, 2012). Untuk tujuan ini, guru perlu mempunyai perangkat pembelajaran yang tepat.

Sebagai salah satu upaya untuk memecahkan masalah di atas, perlu dikembangkan perangkat pembelajaran (RPP, Buku Siswa, LKS, dan Lembar Penilaian) yang dapat digunakan untuk meningkatkan kualitas hasil belajar siswa, khususnya melatihkan keterampilan berpikir kritis dan meningkatkan penguasaan konsep. Keterampilan berpikir kritis dapat dibangun ketika siswa melaksanakan penyelidikan. Ketika siswa melakukan penyelidikan maka siswa berpikir untuk mencari apa yang diketahui dan apa yang tidak diketahui, berpikir untuk memecahkan masalahnya, membuat tahap-tahap penyelidikan, memonitor proses penyelidikan dan kemajuan kearah tujuan saat melaksanakan rencana serta mengevaluasi apa yang sudah dilakukan. Hal ini sependapat dengan Launch Pad (2001) bahwa proses penyelidikan memerlukan penemuan masalah dan pertanyaanpertanyaan untuk menyelidiki, serta mengevaluasi solusi yang dibutuhkan.

Salah satu model pembelajaran yang dapat digunakan memberdayakan keterampilan berpikir kritis siswa adalah model pembelajaran berbasis inkuiri. Menurut National Research Council (2000) inkuiri merupakan suatu kegiatan yang melibatkan siswa melakukan pengamatan, mengajukan pertanyaan, memeriksa buku-buku dan sumber informasi lain, merencanakan penyelidikan, meninjau hasil eksperimen, menganalisis atau menafsirkan data, mengusulkan jawaban terhadap data, memberikan penjelasan terhadap prediksi dan mengkomunikasikan hasil. Proses penyelidikan mengharuskan siswa mengidentifikasi asumsi, menggunakan berpikir kritis dan logis di setiap langkah-langkah penyelidikan dan memberikan penjelasan terhadap solusi alternatif.

Materi koloid sangat cocok diajarkan melalui percobaan atau praktikum. Konsep-konsep dalam materi koloid tentu sangat sulit dipahami siswa jika hanya diajarkan secara verbal tanpa memberikan pengalaman di laboratorium. Oleh karena itu model inkuiri sangat sesuai diterapkan dalam pembelajaran tersebut. Melalui model inkuiri siswa dapat berlatih menemukan dan membangun konsep serta berlatih mengembangkan keterampilan berpikir kritis, sehingga penguasaan konsepnya akan meningkat.

Berdasarkan uraian latar belakang di atas, maka penulis tertarik untuk melakukan penelitian tentang pengembangan perangkat pembelajaran kimia model inkuiri untuk meningkatkan pemahaman konsep dan 
keterampilan berpikir kritis siswa SMA pada materi koloid.

\section{METODE PENELITIAN}

Implementasi penelitian ini menggunakan one group pretest-posttest design, dengan menggunakan satu kelompok subyek (Tuckman, 1978: 42). Gambaran rancangan penelitian ini adalah sebagai berikut:

\section{$\mathrm{O}_{1} \times \mathrm{O}_{2}$}

Keterangan:

$O_{1}$ adalah pre test yang dilakukan untuk mendeskripsikan penguasaan konsep dan keterampilan keterampilan berpikir kritis siswa. $X$ adalah perlakuan dengan menerapkan perangkat pembelajaran model inkuiri selama pembelajaran. $\mathrm{O}_{2}$ adalah post test yang dilakukan untuk mendeskripsikan penguasaan konsep dan keterampilan keterampilan berpikir kritis siswa setelah dilakukan pembelajaran menggunakan perangkat pembelajaran model inkuiri

Uji coba dilakukan di SMAN 6 Surabaya pada kelas XI tahun ajaran 2014/2015. Pada uji coba I melibatkan 38 siswa dan uji coba II sebanyak 112 siswa dengan replikasi sebanyak 3 kelas.Untuk mendukung pencapaian tujuan penelitian, maka dalam proses belajar mengajar digunakan perangkat pembelajaran berupa RPP, Buku Siswa, LKS, dan LP yang dikembangkan peneliti mengadaptasi pengembangan perangkat model Four-D dari Thiagarajan (1974). Perangkat pembelajaran tersebut kemudian divalidasi oleh dua pakar pendidikan. Teknik pengumpulan data pada penelitian ini menggunakan teknik validasi, observasi, angket, dan tes. Hasil implementasi perangkat pembelajaran adalah keterlaksanaan RPP, aktivitas siswa, respon siswa, penguasaan konsep dan keterampilan berpikir kritis.

\section{HASIL PENELITIAN DAN DISKUSI}

\section{A. Validitas Perangkat Pembelajaran}

Validitas perangkat pembelajaran meliputi validitas RPP, Buku Siswa, LKS, dan LP oleh pakar. Hasil analisis penilaian perangkat pembelajaran tersebut oleh dua pakar pendidikan meliputi RPP berkategori sangat baik, Buku Siswa dan LKS berkategori baik, dan LP berkategori valid. Menurut Nur (2012) menyatakan bahwa salah satu faktor yang mempengaruhi kualitas pembelajaran adalah tersedianya perangkat pembelajaran yang berkualitas.

\section{B. Keterlaksanaan RPP}

Keterlaksanaan RPP dapat dilihat dari persentase keterlaksanaan diberikan dua pengamat yang dinyatakan dengan kriteria terlaksana dan tidak terlaksana. Adapun hasil pengamatan keterlaksanaan RPP oleh dua pengamat berkategori sangat baik. Keterlaksanaan RPP tersebut tidak lepas dari peran guru dalam mengelola PBM. Keberhasilan guru dalam mengelola PBM dan suasana belajar merupakan salah satu faktor yang dapat mempengaruhi kualitas pembelajaran (Dimyati, 1994).

\section{Aktivitas Siswa}

Aktivitas siswa diamati dengan Lembar Pengamatan Aktivitas Siswa didapat bahwa aktivitas siswa yang menonjol selama PBM adalah melakukan pengamatan, merencanakan dan melakukan eksperimen. Selanjutnya, aktivitas bertanya dan mengemukakan pendapat lebih menonjol dari aktivitas siswa yang lain. Hal ini memberi bukti bahwa pembelajaran inkuiri berpusat pada siswa (student centered). Sesuai dengan pendapat De Boer (1991 dalam Ibrahim, 2012) bahwa pembelajaran inkuiri merupakan salah satu model pembelajaran yang berperan penting dalam membangun paradigma pembelajaran konstruktivistik yang menekankan pada keaktifan belajar siswa.

\section{Respon Siswa}

Respon siswa positif terhadap pembelajaran model inkuiri dengan pendekatan scientific. Hal ini dapat dimaknai juga bahwa tujuan pengembangan perangkat pembelajaran untuk meningkatkan pemahaman knsep dan melatihkan keterampilan berpikir kritis berhasil. Respon tersebut juga dapat dimaknai bahwa PBM dengan menggunakan perangkat pembelajaran yang dikembangkan telah berhasil membuat hampir seluruh siswa senang dan tertarik saat belajar Kimia. Keberminatan siswa terhadap model pembelajaran sangat baik untuk memotivasi siswa belajar. Menurut beberapa teori bahwa motivasi, ketertarikan, dan keberminatan siswa terhadap pelajaran dan metode pembelajaran dapat meningkatkan motivasi siswa untuk belajar (Nur, 2008). Hal ini dimaknai bahwa apabila siswa memiliki motivasi yang baik, maka siswa akan merasa senang dengan PBM sehingga mereka lebih giat belajar dan mudah memahami kompetensi yang dilatihkan dan harus dikuasai.

\section{E. Penguasaan Konsep}

Tes penguasaan konsep dirancang untuk melihat pemahaman siswa terhadap materi yang dipelajari. Tingkat pemahaman siswa dilihat dari tes penguasaan konsep yang dilakukan sebanyak dua kali, yaitu tes awal (pretest) untuk mengetahui kemampuan awal siswa sebelum diberikan perlakuan dan tes akhir (posttest) untuk mengetahui pemahaman konsep siswa setelah diberikan perlakuan dengan menggunakan model inkuiri dengan pendekatan scientific pada materi koloid. Ketuntasan hasil belajar yang diukur 
berdasarkan indikator dan tujuan pembelajaran yang dikembangkan. Peneliti mengukur serta membandingkan ketuntasan belajar berdasarkan dari nilai yang diperoleh pretest dan posttest. Ketetapan Kriteria Ketuntasan Minimal (KKM) untuk mata pelajaran Kimia di SMA Negeri 6 Surabaya adalah $\geq$ 75 , jadi siswa dianggap tuntas jika hasil belajarnya mencapai 75 .

Hasil yang telah diperoleh dari uji coba 1 pada kelas XI IPA1, uji coba 2 pada kelas XI IPA2, IPA4 dan IPA5 dapat dikemukakan bahwa pelaksanaan pretest dengan objek penelitian masing masing kelas sebanyak 38 siswa, 36 siswa, 38 siswa dan 35 siswa tidak ada satu siswapun yang tuntas dalam pelaksanaan pretest. Selain itu, dari 10 indikator pengetahuan hanya 3 indikator yang tuntas pada pretest, yaitu merumuskan masalah, memperoleh data percobaan dan menganalisis data. Pada pelaksanaan posttest dari semua siswa dari 4 kelas yang mengikuti tes, semua siswa dapat mencapai KKM Kimia, maka kelas tersebut dikatakan tuntas secara klasikal. Sedangkan pada ketuntasan indikator semua indikator sudah tuntas dan siswa mendapatkan nilai di atas KKM. Ketuntasan rata-rata indikator secara keseluruhan dikatakan tuntas karena mencapai KKM sehingga kelas tersebut dapat dikatakan tuntas secara klasikal dan indikator.

Pada saat pelaksanaan pretest tidak ada satu siswa yang tuntas, hal ini disebabkan siswa belum mendapatkan pendalaman mengenai materi koloid, sehingga mereka hanya mampu mengerjakan berdasarkan pengetahuan awal yang mereka miliki dan banyak siswa yang masih mengosongkan lembar jawaban soal. Hal seperti ini berbeda pada pelaksanaan posttest, dimana siswa telah mendapatkan materi mengenai koloid secara mendalam, sehingga semua siswa tuntas.

Kondisi seperti ini tampak pada kelas XI IPA1 dan pada waktu uji coba 2 pada kelas XI IPA2,IPA4 dan IPA5 yang menunjukkan adanya peningkatan penguasaan konsep siswa. Hal ini sesuai dengan pengukuran indeks sensitivitas tiap butir soal pada masing masing kelas yang menunjukkan bahwa indeks sensitivitas pada soal yang dikembangkan secara berturut turut rata-ratanya sebesar $0,56,0,60,0,44$ dan 0,46 sehingga soal yang diberikan dapat dikatakan sensitif. Ini menunjukkan bahwa butir soal tersebut memiliki kepekaan yang cukup terhadap efek pembelajaran yang diberikan, sesuai dengan pernyataan Grondlund (1995), jika indeks butir soal mempunyai sensitivitas yang tinggi $(\geq 0,30)$, maka mempunyai efek kepekaan terhadap pembelajaran yang dilakukan pada masing masing kelas.

Kemampuan siswa dalam menerima materi (penguasaan konsep) dapat dianalisis dengan menggunakan Gain Score yang ternomalisasi (N-Gain).
Hasil N-Gain pada kelas menunjukkan bahwa: 1). pada kelas XI IPA1 ada 4 orang siswa memiliki skor gain sedang sedangkan 34 siswa memiliki skor gain yang tinggi yaitu $\geq 0,7$, secara rata-rata ( $N-G a i n)$ siswa sebesar 0,80 (gain tinggi) ini berarti kemampuan penguasaan konsep kelas XI IPA 1 yang diberikan melalui model pembelajaran inkuiri dengan pendekatan scientific tinggi. 2). pada kelas XI IPA 2 ada 10 orang siswa memiliki skor gain sedang sedangkan 26 siswa memiliki skor gain yang tinggi yaitu $\geq 0,7$, secara ratarata (N-Gain) siswa sebesar 0,74 (gain tinggi) berarti kemampuan penguasaan konsep kelas XI IPA 2 yang diberikan melalui model pembelajaran inkuiri dengan pendekatan scientific tinggi, 3). pada kelas XI IPA 4 ada 1 orang siswa memiliki skor gain rendah, 23 orang siswa memiliki skor gain sedang, 14 siswa memiliki skor gain yang tinggi yaitu $\geq 0,7$, secara rata-rata $(\mathrm{N}$ Gain) siswa sebesar 0,65 (gain sedang) berarti kemampuan penguasaan konsep kelas XI IPA 4 yang diberikan melalui model pembelajaran inkuiri dengan pendekatan scientific sedang, 4). pada kelas XI IPA 5 ada 30 orang siswa memiliki skor gain sedang, 5 siswa memiliki skor gain yang tinggi yaitu $\geq 0,7$, secara ratarata (N-Gain) siswa sebesar 0,63 (gain sedang) berarti kemampuan penguasaan konsep kelas XI IPA 5 yang diberikan melalui model pembelajaran inkuiri dengan pendekatan scientific sedang. Hal ini sesuai dengan Hake (1999), bahwa Gain skor ternormalisasi yang tinggi/sedang menunjukan tingkat efektifitas pembelajaran.

\section{F. Kemampuan Berpikir Kritis}

Kemampuan berpikir kritis yang diamati dalam penelitian ini adalah menjawab pertanyaan klarifikasi, mempertimbangkan kredibilitas sumber, membuat induksi dan mempertimbangkan hasil induksi, mendefinisikan istilah berdasarkan konteks atau situasi tertentu, menentukan suatu tindakan dengan cara merumuskan alternatif yang memungkinkan untuk memecahkan masalah. Tes keterampilan berpikir kritis terdiri dari lima butir soal dalam bentuk uraian (essay).

Proses pembelajaran kimia yang menerapkan model inkuiri dengan pendekatan scientific terbukti mampu mengembangkan kemampuan bernalar dan berpikir sistematis sehingga dapat meningkatkan keterampilan berpikir kritis siswa. Tahapan - tahapan inkuiri yang dilakukan siswa selama pembelajaran telah mampu melatihkan keterampilan berpikir kritis siswa.

Fase 1 model pembelajaran berbasis inkuiri, siswa dihadapkan pada pertanyaan yang berkaitan dengan kehidupan sehari-hari. Siswa diberikan kebebasan dalam mengungkapkan pendapatnya. Hal ini dilakukan dengan tujuan untuk memberdayakan keterampilan berpikir kritis siswa dalam memberikan argumen yang jelas logis dengan cara memicu siswa untuk 
mengungkapkan pendapatnya berdasarkan pengetahuan-pengetahuan yang ada pada siswa tanpa ada kekangan dari siapapun. Hal ini sejalan dengan pendapat Ennis (1996) dan Fisher (2006) bahwa dalam mengajarkan keterampilan berpikir kritis hal utama yang dilakukan adalah memberikan situasi di mana seseorang dapat mengemukakan pendapatnya secara bebas.

Fase 2 model pembelajaran berbasis inkuiri, siswa dituntut untuk merumuskan suatu masalah. Pada proses pembelajarannya, siswa diminta untuk mengamati gambar yang terdapat pada LKS dan kemudian siswa dimita untuk menuliskan hasil pengamatan dan menemukan masalah yang akan diselesaikan. Pada fase ini, keterampilan siswa dalam menjawab pertanyaan klarifikasi diberdayakan, yaitu memicu pengetahuan dan keterampilan siswa dalam menentukan masalah utama yang akan diselesaikan. Hasil tes keterampilan berpikir kritis dari 4 kelas sebesar 0,84 pada kelas XI IPA1, 079 pada kelas XI IPA2, 0,82 pada kelas XI IPA4, 0,66 pada kelas XI IPA5 $(>0,3)$ menunjukkan hasil yang peka. Hal ini juga ditandai dengan tes penguasaan konsep pada masing masing kelas yang memberikan hasil sebanyak $100 \%$ siswa tuntas pada indikator merumuskan masalah.

Fase 3 model pembelajaran berbasis inkuiri, siswa dituntut untuk dapat merumuskan hipotesis dari rumusan masalah pada fase 2. Pada proses pembelajarannya, siswa diminta untuk mengumpulkan informasi-informasi yang terkait dengan masalah dan menjadikannya sebagai dasar untuk merumuskan hipotesis. Pada fase ini, keterampilan siswa dalam memilih sumber yang kredibel diberdayakan, yaitu memicu pengetahuan atau keterampilan siswa dalam memilih sumber-sumber yang dianggap kredibel dan menjadikannya sebagai dasar dalam merumuskan hipotesis. Keterampilan siswa dalam menganalisis sumber yang tepat pada tes berpikir kritis sebesar 0,84 pada kelas XI IPA1, 0,66 pada kelas XI IPA2, 0,76 pada kelas XI IPA4, 0,45 pada kelas XI IPA5 $(>0,3)$ dengan kategori peka.

Fase 4 model pembelajaran berbasisis inkuiri siswa diminta untuk menentukan variabel, merumuskan definisi operasinal variabel, merumuskan cara penyelesaian masalah dan menganalisis data hasil percobaan yang meliputi pemberian penjelasan terhadap data hasil temuan berdasarkan konsep atau teori. Pada kegiatan merumuskan definisi operasional variabel, siswa dituntut untuk merumuskan suatu definisi dari suatu variabel tentang hal yang akan dilakukan secara tepat. Dalam hal ini keterampilan siswa dalam membuat suatu definisi berdasarkan kontek atau situasi tertentu diperdayakan dalam proses pembelajaran. Hal ini ditandai dengan keterampilan siswa dalam membuat definisi berdasarkan situasi sebesar 0,45 pada kelas XI IPA1, 0,63 pada kelas XI IPA2, 0,71 pada kelas XI IPA4, 0,39 pada kelas XI IPA5 dengan kategori peka.

Fase 5 dari model pembelajaran berbasis inkuiri, siswa dituntut untuk dapat merumuskan kesimpulan berdasarkan data hasil percobaan atau kajian konsep. Pemberdayaan keterampilan siswa dalam merumuskan kesimpulan tergambar dari pertanyaan-pertanyaan dalam LKS bagian penarikan kesimpulan berdasarkan data hasil percobaan dan analisis konsep yang digunakan untuk menyelesaikan masalah yang diberikan. Setelah siswa mengumpulkan data atau kajian konsep selanjutnya siswa menyimpulkan hasil yang didapat dan kemudian membandingkannya dengan hipotesis atau dugaan yang dibuat siswa sebelumnya. Hal ini diperkuat dengan tes hasil berpikir kritis yang menunjukkan keterampilan siswa dalam merumuskan kesimpulan berdasarkan data sebesar 0,92 pada kelas XI IPA1, 0,82 pada kelas XI IPA2, 0,87 pada kelas XI IPA4, 0,58 pada kelas XI IPA5 dengan kategori peka.

Fase 6 dari model pembelajaran berbasis inkuiri, siswa dituntut melakukan refleksi dengan cara mempersentasikan hasil yang didapat dalam diskusi kelas. Masing-masing kelompok dapat menerima atau menolak hasil pekerjaan kelompok lain dan dapat memberikan solusi alternatif kepada kelompok lain untuk memperoleh hasil yang tepat. Dalam proses pembelajarannya belum berjalan maksimal. Tahap refleksi pada pertemuan pertama hanya sekedar penyampaian kesimpulan dari kelompok yang persentasi dan tidak terjadi diskusi kelas yang dikarenakan keterbatasan waktu pembelajaran. Namun pada pertemuan 2 dan 3 tahap refleksi berjalan maksimal. Akibatnya keterampilan siswa dalam pemberian solusi alternatif diberdayakan pada pada proses pembelajarannya. Hal ini tercermin dari hasil tes berpikir kritis yang menunjukkan indek sensitivitas yang diperoleh sebesar 0,63 pada kelas XI IPA1, 0,79 pada kelas XI IPA2, 0,82 pada kelas XI IPA4, 0,39 pada kelas XI IPA5 dengan kategori peka.

Berdasarkan hasil analisis data menunjukkan bahwa sensitivitas butir soal tergolong dalam kategori peka pada setiap indikatornya. Pada akhir pembelajaran seluruh siswa pada masing masing kelas mampu menjawab soal-soal tentang berpikir kritis yang didapatkan pada postest. Peningkatan kemampuan berpikir kritis siswa secara klasikal yang diukur mengunakan N-Gain sehingga diperoleh skor 0,78 pada kelas XI IPA1 0,78 pada kelas XI IPA2, 0,77 pada kelas XI IPA4, 0,47 pada kelas XI IPA5, yang artinya siswa mengalami peningkatan keterampilan berpikir kritis setelah pembelajaran berlangsung. Hal ini sesuai dengan Hake 1999, siswa dikatakan mampu berpikir kritis apabila terdapat peningkatan hasil dari tes 
sebelum diberikan perlakuan (pretest) dan setelah diberikan perlakuan (posttest). Selain itu juga diperoleh hasil rerata skor saat pretest berpikir kritis kelas XI IPA1 sebesar 66,18 dan mengalami peningkatan pada saat posttest yaitu 91,97, rerata skor saat pretest berpikir kritis kelas XI IPA2 sebesar 42,22 dan mengalami peningkatan pada saat posttest yaitu 87,36 , rerata skor saat pretest berpikir kritis kelas XI IPA4 sebesar 48,42 dan mengalami peningkatan pada saat posttest yaitu 88,03 , rerata skor saat pretest berpikir kritis kelas XI IPA5 sebesar 49,14 dan mengalami peningkatan pada saat posttest yaitu 75,57.

Peningkatan ini disebabkan adanya penerapan model inkuiri dengan pendekatan scientific yang dilatih kepada siswa untuk merangsang keterampilan berpikir kritis siswa selama proses pembelajaran berlangsung. Hal ini sesuai dengan Filsaime (2008), bahwa proses pembentukan berpikir kritis kepada siswa tidak timbul secara kebetulan tetapi memerlukan persiapan, seperti kemampuan berpikir dapat ditingkatkan melalui bertanya kritis, pertanyaan-pertanyaan yang menggunakan rangkaian kata dan kontruksi yang mendalam sangat mungkin menghasilkan daya pikir tingkat tinggi bagi siswa. Kegiatan bertanya untuk melatih berpikir logis, runut, dan sistematis, dengan menggunakan kapasistas berfikir tingkat tinggi dapat dilatihkan dengan menggunakan pendekatan scientific, karena pada pendekatan scientific meltihkan kegiatan mengamati, menanya, menalar, mencoba, dan mengkomunikasikan sehingga siswa akan terlatih untuk berpikir kritis. Hal ini sejalan dengan Silverman dan Smith dalam Filsaime (2008), yaitu salah satu hal seseorang dikatakan menunjukkan berpikir kritis apabila mampu mensintesis informasi sampai pada kesimpulan yang masuk akal.

\section{KESIMPULAN}

\section{A. Simpulan}

Berdasarkan hasil penelitian dan pembahasan serta temuan-temuan di dalam penelitian, dapat disimpulkan bahwa perangkat pembelajaran model inkuiri praktis, efektif dan layak digunakan dalam meningkatkan penguasaan konsep dan melatihkan keterampilan berpikir kritis. Kepraktisan, keefektifan dan kelayakan perangkat pembelajaran dinilai dari hasil validasi perangkat pembelajaran, keterlaksanaan RPP, aktivitas siswa, respon siswa, dan hasil belajar siswa (penguasaan konsep dan keerampilan berpikir kritis).

\section{REFERENSI}

Dimyati, M. (1994_. Belajar dan Pembelajaran. Jakarta: Rineka Cipta.

Ennis, R.H. (1996). Critical Thinking. New York: Prentice Hall.

Filsaime, D.K. (2008). Menguak Rahasia Berfikir Kritis Dan Kreatif. Jakarta: Prestasi Pustakary.

Fisher. (2006). Critical Thinking: An Introduction (terjemahan). Alih bahasa: Benyamin Hadinata. Jakarta: Erlangga.

Gronlund, N.E. \& Robert, L.L. (1995). Measurement and assessment in Teaching $7^{\text {th }}$ Edition. USA: Prentice-hall, Inc.

Hake, R. R. (1999). Analyzing Change/Gain Scores . USA: Dept. of Physics, Indiana University.

Ibrahim, M. (2012). "Pembelajaran Inkuiri". Makalah disajikan pada Diklat Nasional, Surabaya.

National Research Council. (2000). Inquiry And The National Science Education Standards: A Guide for Teaching and Learning. New York: National Academic Press.

Nur, M. (2008). Pengajaran Berpusat Pada Siswa dan Pendekatan Konstruktivis dalam Pengajaran. Edisi kelima. Surabaya: Unipress Unesa. (2012). "Pengembangan Bahan Ajar untuk Memberi Kemudahan Guru Mengimplementasikan Inovasi Pembelajaran.” Makalah yang disajikan pada Simposium Nasional Hasil Penelitian tentang Guru tanggal 9 Juni 2012 di Kampus Unesa Ketintang.

Thiagarajan, S., Semmel, D.S., \& Semmel, M.I. (1974). Instructional Development for Training Teacher of Exceptional Childern. Minneapolis, Minnesota: Leadership Training Institute/Special Education, University of Minnesota

Tuckman, B. W. (1978). Conducting Educational Research. San Diego: Harcourt Brace Jovanovich, Publisher. 